\title{
Penelitian
}

\section{Faktor-faktor Penyebab Gerakan Sosial Mahasiswa}

\author{
Andik Matulessy \& Djamaludin Ancok
}

\section{Abstract}

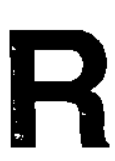

ecently, there are many social movements which arise in many parts of big city in Indonesia. These days, social movement, that is known as a demonstrasi or unjuk rasa seem to become a trend and very popular inside the society in order to get what they want but unreachable.

Most of these acts are pointed to the government, both in civil and military. While, the majorities that take apart in this social movement are the students from all universities, both state universities and the private ones. They are not only concerning about political matter, but also concerning about many social problems.

The objective of this research is to prove Orum's theory which shows a causing factor of individual participation in doing a social movement that is determined with 6 important variable. They are: Political Trust, Political Efficacy, Unstructured Work Routine, Subjective Dissatisfaction, Subgroup Identification, and Self Esteem.
The subjects of this study were 139 students, male and female, both activist and non-activist that spread in many universities, both state and private in Yogyakarta and Surabaya. Seven scales were used for examinting the participation on social movement.

The result of data analyses by using Path Analysis, finds an output which fits with Orum's Theory, that is: There is a positive correlation between unstructured study routine and participation in the social movement (1); between subgroup identification and participation in the social movement (2). There is a negative correlation between subjective dissatisfaction and political trust (3).

On aothe hand, another result that is not fit with the Orum's Theory are: There is no significat correlation between political trust and participation in the social movement (4); between political efficacy and participation in the social movement (5); between subgroup identification' and political trust (6); between self esteem and political efficacy (7). 
Topik: Faktor-Faktor Penyebab Gerakan Sosial ..., Andik Matulessy dan Djamaludin Ancok

\section{Latar Belakang Penelitian}

Akhir-akhir ini semakin banyak muncul kasus gerakan sosial (social movement) di sebagian besar kota di Indonesia. Gerakan sosial yang lebih dikenal dengan istilah unjuk rasa atau demonstrasi, pada era sekarang ini nampaknya menjadi trend dan amat populer bagi seluruh lapisan masyarakat untuk mendapatkan sesuatu yang diinginkan dan tidak teraih, terutama para mahasiswa berbagai perguruan tinggi.

Sebagaimana diketahui generasi muda, khususnya mahasiswa menjadi faktor yang menentukan dalam mewarnai situasi politik di Indonesia. Bertolak dari dimensi historis, mahasiswa memang memiliki posisi strategis, sedang dalam konteks perspektif kehidupan kontemporer mahasiswa memiliki peran strategis (Darmawan dalam Nasri, 1993).

Hal tersebut terbukti bahwa sejak sebelum kemerdekaan sampai sekarang banyak tumbuh pergolakan politik yang dimotori oleh mahasiswa berbagai perguruan tinggi. Hal itu nampak dari meningkatnya berbagai macam protes/unjuk rasa dari mahasiswa tersebut dari tahun ke tahun. Dalam gerakan sosial mahasiswa tersebut tercakup juga protes yang berlatar belakang politis.

Keberadaan dan dinamika mahasiswa dapat menjadi tolok ukur situasi politik di sebuah negara. Menurut Altbach (1988), mahasiswa terutama di negara Dunia Ketiga dalam konteks suatu gerakan mahasiswa pada kurun waktu 1960-an mempunyai peran yang penting sebagai suatu kekuatan sosial politik, karena mereka amat responsif terhadap kondisi suatu sistem politik. Terutama sekali bila dikaitkan dengan tidak berfiungsi maksimalnya infrastruktur dan suprastruktur politik pada saat isu krusial terjadi. Oleh karena itu dapat disimpulkann bahwa ada 2 fungsi gerakan mahasiswa dalam proses perubahan, yaitu menumbuhkan perubahan sosial dan mendorong perubahan politik. Hal tersebut didukung oleh pendapat Hagopian (1978) bahwa pada dasarnya studi tentang gerakan. (movement) merupakan studi tentang aspek dinamis dari kehidupan politik. Seperti diketahui semua peristiwa politik selalu mengisyaratkan interaksi segmen sosial, mobilisasi, dan pengorganisasian sosial yang pada akhirnya akan mempengaruhi suatu sistem politik.

Lipset (1968) mencatat peristiwa yang menunjukkan peran penting gerakan mahasiswa dalam memunculkan suatu perubahan sosial politik suatu negara. Peristiwa tersebut antara lain; jatuhnya pemerintahan diktator Juan Peron di Argentina (1955); Perez Jimenez di Venezuela (1958); mendudukkan kembali Ngo Din Diem di Vietnam (1963); melakukan kekerasan Treaty di Jepang tahun 1960 yang memperkuat kembali pemerintahan Kishi; demonstrasi Oktober 1956 di Polandia; dan gerakan menjatuhkan Soekarno tahun 1966 di Indonesia.

Mas'oed \& MacAndrews (1986) menyatakan bahwa partisipasi politik berupa demonstrasi, protes, dan tindak kekerasan ini biasanya dipergunakan individu untuk mempengaruhi kehidupan politik dan kebijaksanaan pemerintahan, bila bentuk aktivitas lain tidak bisa dilakukan atau tidak efektif. Sedangkan E. Wight Bakke (dalam Haryanto, 1987) berpendapat bahwa munculnya gerakan mahasiswa dalam konteks perilaku kolektif muncul karena isu krusial yang disebabkan oieh aspek fluktuatif dari kondisi sosial, ekonomi, dan politik, serta aspek spontanitas sehingga terjadi suatu partisipasi politik non-rutin (demonstrasi, untuk rasa, boikot).

Sebagian besar unjuk rasa ini ditujukan pada aparat pemerintah, baik sipil maupun militer. Sementara itu mayoritas yang ber- 
partisipasi dalam gerakan sosial adalah para mahasiswa, baik yang berasal dari Perguruan Tinggi Negeri maupun Swasta. Bagaimanapun juga tidak dapat disangsikan lagi bahwa mahasiswa mempunyai peran yang vital sebagai agent of change, agent of modernization, dan agent of development dalam segenap bidang kehidupan politik, sosial, ekonomi dan budaya (Darmawan dalam Nasri, 1993). Sampai sekarangpun angkatan muda, khususnya mahasiswa menjadi tulang punggung dalam memberi warna kehidupan politik di dalam maupun di luar negeri.

Melihat hal-hal yang diperjuangkan mahasiswa di atas nampak sekali bahwa terjadi perubahan jalur gerakan mahasiswa yang mulai tidak hanya mempersoalkan masalah politik, namun demikian mulai menyangkut persoalan-persoalan kondisi sosial atau isu problem yang langsung terjadi di masyarakat terutama kalangan bawah, antara lain: memprotes pemberian ganti rugi yang tidak sesuai bagi tanah rakyat yang tergusur proyek pemerintah; seperti waduk Kedung Ombo \& Nipah.

Namun demikian bila mengamati kondisi gerakan sosial mahasiswa pada periode tahun 1993-1996 nampak sekali perubahan kecenderungan gerakan mahasiswa untuk kembali pada gerakan-gerakan yang bermuatan politis. Hal itu didasari oleh pandangan bahwa selama ini pembangunan ekonomi dilakukan di atas kontrol politik yang ketat, sehingga membuat hak-hak politik masyarakat banyak yang ditindas (Pijar, 1996).

Gerakan sosial dapat didefinisikan sebagai gerakan suatu organisasi atau sekelompok organisasi yang bermaksud mengadakan perubahan terhadap struktur sosial yang sudah ada sebelumnya (Orum, 1974; Stallings, 1973; Wiggins et.al., 1980). Sementara itu DiRenzo (1990) mendefinisikan gerakan sosial sebagai perilaku dari sebagian anggota masyarakat untuk mengoreksi kondisi yang banyak menimbulkan problem atau tidak menentu, serta memunculkan kehidupan baru yang lebih baik.

Gerakan sosial yang banyak muncul sekarang mempunyai karakteristik tertentu, seperti yang diungkapkan oleh Snow dan Oliver (dalam Cook et.al., 1995), social movement tercak̈up suatu pengorganisasian suatu gerakan secara lebih kontinu untuk mencapai suatu perubahan tertentu pada kelompok atau masyarakat (Snow \& Oliver dalam Cook et.al., 1995; Lindzey \& Aronson, 1975; Orum \& Stailing dalam Allen et. al, 1980).

Secara lebih luas, Orum (Allen et.al., 1980) mengemukakan tujuh variabel yang berkaitan dengan alasan individu untuk berpartisipasi dalam gerakan sosial yakni: Participation, Political Trust, Political Efficacy, Unstructured Work Routine, Subjective Dissastisfaction, Subgroup Identification, Self Esteem. Dinamika model kausal dari A.M. Orum digambarkan sebagai berikut:

\section{Gambar 1}

Model Kausal Partisipasi dalam Gerakan Sosial Orum

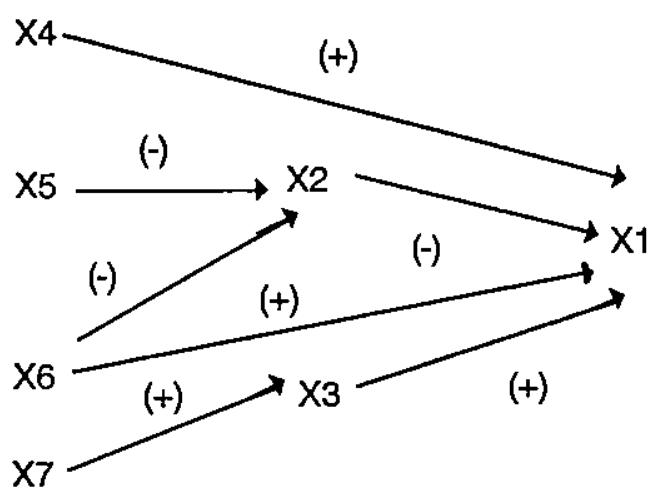

Keterangan:

$\mathrm{X} 1=$ Participation

$\mathrm{X} 2=$ Political Trust 
Topik: Faktor-Faktor Penyebab Gerakan Sosial ..., Andik Matulessy dan Djamaludin Ancok

\section{$\mathrm{X} 3=$ Political Efficacy \\ $\mathrm{X} 4=$ Unstructured Work Routine \\ $\mathrm{X}_{5}=$ Subjective Dissatisfaction \\ $\mathrm{X} 6=$ Subgroup Identification \\ $X 7=$ Self Esteem}

\section{Cara Penelitian}

'Pénelitian ini menggunakan subjek sebanyak 139 mahasiswa, laki-laki dan wanita, baik aktifitas maupun yang nonaktivis, yang tersebar di berbagaj Perguruan Tinggi Negeri dan Swasta di Yogyakarta dan Surabaya. Studi dilakukan dengan menggunakan tujuh skala penelitian, yang masing-masing mengukur tujuh variabel. Analisis data dengan menggunakan uji jalur (Path Analysis, Statistical Program for Social Sciences/SPSS PC +6.0 version) serta model persamaan struktural (EQS Structural Equation Program, Multivariate Software, Inc. Version 5.1, 1985-1995). Setiap pengukuran menggunakan taraf kepercayaan $5 \%$.

\section{Hasil Utama dan Pembahasan}

Hasil analisis secara lengkap dapat dilihat gambar di bawah ini:

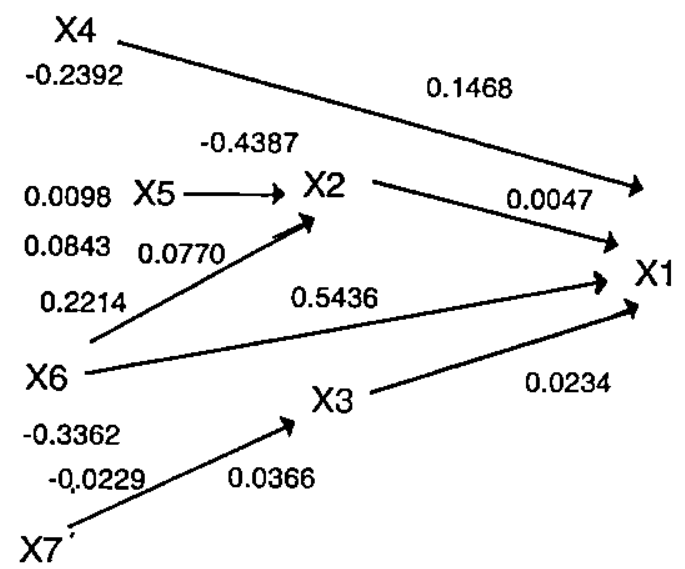

Hasil Uji Analisis Mode! Kausal

Partisipasi Gerakan Sosial

X1 $=$ Participation
X2 $=$ Poltical Trust
X3 $=$ Political Efficacy
X4 $=$ Unstructured Work Routine
X5 $=$ Subjective Dissatisfaction
X6 $=$ Subgroup Identification
X7 $=$ Self Esteem

Berdasarkan hasil analisis tersebut di atas, dapat diambil kesimpulan beberapa hal, antara lain:

1. Ada korelasi positif yang signifikan antara rutinitas kuliah yang tidak terstruktur dengan partisipasi dalam gerakan sosial $\left(r_{1.4}=0.1468 ; p=\right.$ 0.045)

Hasil ini sesuai dengan pendapat Orum (dalam Allen et.al., 1980), yang menemukan adanya keterkaitan antara struktur atau tidaknya jadwal kerja individu dengan partisipasi dalam gerakan sosial.' Hal tersebut berarti aktivis mampu melakukan kegiatan demonstrasi, karena adanya waktu yang banyak untuk berkegiatan. Di sisi lain disebabkan pula oleh kemampuan untuk mengatur jadwal waktu, serta adanya fleksibilitas dalam melakukan kegiatan antara kuliah dan kegiatan lain. Berlainan dengan para mahasiswa non-aktivis yang mempunyai waktu yang padat untuk perkuliahan, mereka cenderung tidak ada waktu lagi untuk melakukan kegiatan lain.

Selain itu dilihat dari perbandingan mean empiris jadwal studi yang tidak terstruktur pada subjek yang ikut unjuk rasa ( $\mathrm{Xe} 1=26.58$ ) dan subjek yang tidak ikut serta unjuk rasa ( Xe2 =24.83), menunjukkan bahwa subjek yang ikut serta dalam unjuk rasa cenderung lebiti mempunyai jadwal studi yang tidak terstruktur dibanding subjek yang nonaktivis. Namun demikian dibandingkan dengan mean hipotesis jadwal studi yang tidak terstruktur $(X h=20)$, menun- 
jukkan bahwa kedua kelompok mempunyai jadwal studi yang tidak terstruktur.

2. Tidak ada korelasi yang signifikan antara kepercayaan terhadap sistem politik yang ada dengan partisipasi dalam gerakan sosial $\left(r_{1.2}=0.0047 ; p\right.$ $=0,479$ )

Hasil ini bertentangan dengan pendapat Orum (dalam Allen et.al., 1980) bahwa individu yang merasa tidak percaya dengan sistem politik yang ada, lebih berpartisipasi dalam aktivis gerakan sosial.

Hal ini secara teoritis memang tidak ada dasar teori yang mendukung pendapat ini, karena sebagian besar mendukung teori yang menyatakan bahwa semakin tidak percaya individu terhadap suatu sistem, baik itu pemerintah, organisasi, atau kelompok, maka akan mengarahkan pada dorongan untuk berpartisipasi dalam gerakan sosial.

Namun demikian bila didasarkan pengamatan, kadang-kadang individu yang melakukan gerakan sosial, ternyata tidak didasari oleh percaya atau tidaknya individu terhadap sistem yang ada, karena mereka cenderung acuh tak acuh dengan sistem politik yang ada. Artinya menjadi tidak terdeteksi secara nyata rasa percaya atau tidak individu terhadap sistem politik yang ada, di satu sisi mereka percaya dengan beberapa komponen sistem politik, misalnya organisasi profesi, sistem peradilan Tata Usaha Negara, DPRD I. Sementara di sisi lain mereka tidak percaya dengan komponen sistem politik yang lain, yakni sistem pemerintahan, pemilu, DPR Pusat. Jadi belum dapat dikatakan bahwa faktor ketidakpercayaanlah yang mendorong terjadi suatu gerakan. Apalagi bila dilihat dari perbandingan hasil rerata empiris ke- lompok aktivis $(X e 1=65,86)$ dan kelompok non-aktivis ( $\mathrm{Xe2}=77.85$ ), ternyata di atas rerata hipotetis $(\mathrm{Xh}=$ 63), artinya kedua kelompok masih dalam taraf kepercayaan pada sistem politik yang tinggi dibanding rerata hipotetik.

3. Ada korelasi positif yang sangat signifikan antara identifikasi terhadap kelompok yang melakukan gerakan sosial dengan partisipasi dalam gerakan sosial $\left(r_{1.6}=0.5436 ; p=0.000\right)$.

Hasil ini sesuai dengan teori Orum (Allen et.al., 1980), yang menyatakan adanya hubungan di antara kedua variabel di atas. Jadi individu yang semakin mempunyai identifikasi tinggi dengan kelompok pengunjuk rasa, maka mreka cenderung lebih berpartisipasi dalam gerakan sosial. Hal tersebut karena individu yang mengidentifikasikan diri dengan suatu kelompok, maka mereka menjadikan sistem norma, sikap, tingkah laku kelompok sebagai bagian dari dirinya. Ikatan yang terjadi atau hubungan sosial dalam proses identifikasi antara individu dan kelompok, teryata lebih mendalam daripada hubungan yang berlangsung melalui proses sugesti atau imitasi (Gerungan, 1996).

Hal ini juga didukung pula oleh hasil perbandingan rerata empiris identifikasi pada kelompok pengunjuk rasa, antara aktivis (Xe1 $=127.83$ ) dengan nonaktivis ( $\mathrm{Xe} 2=106.14)$; nampak sekali bahwa kelompok aktivis yang mengikuti unjuk rasa cenderung lebih mengidentifikasikan diri dengan kelompok pendemo dibanding kelompok nonaktivis. Namun demikian dilihat dari perbandingan kedua kelompok dengan rerata hipotesis identifikasi kelompok $(\mathrm{Xh}=61.5)$, nampak sekali bahwa kedua kelompok (aktivis dan non- 
aktivis) sebenarnya mempunyai identifikasi yang tinggi dengan kelompok pengunjuk rasa. Atau dengan kata lain pada dua kelompok tersebut, ada keinginan untuk meniru aktivitas kelompok pengunjuk rasa, berpandangan positif terhadap mereka, dan menginginkan mendapatkan hasil positif dari kegiatan kelompok pengunjuk rasa.

4. Tidak ada korelasi antara kemımpuan berperan terhadap sistem politik dengan partisipasi dalam gerakan sosial $\left(r_{1,3}=0.0234 ; p=0.394\right)$.

Hasil ini tidak sesuai dengan teori Orum (dalam Allen et.al., 1980), yang menemukan individu yang mempunyai perasaan berperan yang tinggi akan lebih berpartisipasi dalam gerakan sosial dibanding individu yang tidak mempunyai kemampuan untuk berperan dalam kehidupan sosial politik. Hal tersebut karena hampir sebagian besar dari pengikut gerakan sosial ternyata didasari oleh ketidakmampuan untuk berperan sistem sosial politik yang ada, sebagai contoh gerakan yang dilakukan oleh orang-orang kulit hitam, suku Indian, suku Aborijin, kelompok Gay, Feminis, yang muncul akibat adanya ketidakadilan (DiRenzo, 1990). Begitu pula munculnya gerakan sosial yang terjadi di Indonesia, lebih banyak didasarkan pada ketidakmampuan untuk berperan memberikan solusi terhadap sistem politik yang ada.

Seperti dikemukakan Mas'oed \& MacAndrews (1986) bahwa partisipasi politik berupa demonstrasi, protes dan tindak kekerasan biasanya digunakan individu untuk mempengaruhi kehidupan politik dan kebijaksanaan peme-rintahan, bila bentuk aktivitas lain tidak bisa dilakukan atau tidak efektif. Hal di atas menunjukkan bahwa karena adanya keterbatasan kemampuan untuk berperan dalam sistem politik yang ada membuat individu melakukan kegiatan unjuk rasa. Ini bertolak belakang dengan teori yang ada bahwa individu yang berperan dalam sistem politik yang ada yang lebih berpartisipasi dalam kegiatan gerakan sosial. Bahkan individu yang merasa berperan dalam sistem politik yang ada, misalnya aparat birokrasi, pengusaha yang mempunyai aksebilitas kepemerintahan, ternyata tidak berpartisipasi dalam gerakan sosial/demo. Hal ini bertolak belakang dengan kelompok-kelompok yang merasa kurang berperan, cenderung untuk berpartisipasi dalam gerakan sosial.

Secara lebih rinci dapat diterangkan pula dari hasil perbandingan rerata empiris pada kedua kelompok (aktivis dan non-aktivis), ternyata kelompok aktivis mempunyai rerata empiris yang lebih rendah (Xe1 = 73) dibandingkan dengan rerata empiris kelompok nonaktivis (Xe2 = 76.04). Hal ini berarti kelompok non-aktivis lebih merasa berperan dalam sistem politik dibandingkan kelompok aktivis. Jadi dengan kata lain bahwa tidak selalu bahwa kelompok aktivis yang berpartisipasi dalam gerakan sosial didasari oleh kemampuan berperan terhadap sistem perpolitikan yang ada. Namun demikian bila dibandingkan dengan rerata hipotetik kemampuan berperan pada sistem politik yang ada $(X h 5=66.5)$, kedua kelompok mempunyai kemampuan di atas rerata hipotetiknya.

5. Ada korelasi negatif yang sangat signifikan antara ketidakpuasan subjektif dengan kepercayaan terhadap sistem politik yang ada $\left(r_{2.5}=-0.4387 ; p=\right.$ 0.000).

Hal ini sesuai dengan teori Orum (Allen et.al., 1980) yang menyatakan 
bahwa deprivasi relatif (ketidakpuasan) yang semakin meningkat akan mengarahkan pada ketidakpercayaan pada sistem politik yang ada. Demikian pula menurut Gescwender (1968), yang menyatakan bahwa perasaan kekurangan individu akan berbagai hal yang menyangkut kehidupan sosialnya atau lebih khusus lagi meningkatnya jarak sosial antara perasaan individu tentang apa yang ia dapatkan dan apa yang secara aktual ia dapatkan, akan mengarahkan individu pada ketidakpercayaan akan sistem politik yang ada.

Pendapat lain dari Feuer (1969) dan Lofland \& Stark (1965), menemukan adanya hubungan yang erat antara tipe kebutuhan atau permasalahan individu dengan tipe gerakan. Artinya semakin meningkat perasaan kekurangan individu, maka mereka cenderung menyalahkan sistem politik yang ada.

Memang tidak dapat disangsikan lagi bahwa ketegangan-ketegangan sosial yang terjadi di Indonesia maupun negara-negara lain seperti Korea Selatan, Filipina, RRC, yang intinya mengarah ketidakpercayaan pada sistem politik yang ada berawal dari ketidakpuasan individu akan berbagai hal yang menyangkut kehidupan sosialnya. Sebagai contoh nyata adalah penanganan Kasus Udin, wartawan Bernas yang dianggap berlarut-larut, penanganan Marsinah atau pemberlakuan Undang-Undang Perburuhan yang diberlakukan di Korsel, semua dianggap tidak memenuhi harapan masyarakat yang mendambakan sekali kebutuhan mendasar untuk diperlakukan secara adil.

6. Tidak ada korelasi yang signifikan antara identifikasi dengan kelompok yang melakukan gerakan sosial dengan kepercayaan terhadap sistem politik yang ada $\left(r_{26}=-0.0770 ; p=0.188\right)$.

Hasil ini tidak sesuai dengan hasil penelitian Orum (Allen, et.al., 1980), yang menemukan keterkaitan antara dua variabel di atas. Hal tersebut dapat diterangkan bahwa individu yang masuk dalam kelompok pengunjuk rasa tidaklah selalu didasarkan oleh rasa percaya atau tidak pada kelompok tersebut. Namun lebih pada hal-hal positif yang individu dapatkan atau kepuasan yang didapatkan oleh mereka. Sebagai contoh adalah proses terjadinya kelompok yang dapat diterangkan dengan social reinforcement exchange theory (Walgito, 1995). Teori ini menerangkan bahwa individu yang masuk dalam suatu kelompok dan mendapatkan kepuasan (reward), maka akan meningkatkan interaksi individu dengan kelompok. Di dalam interaksi tersebut ada harapan minimal yang dianggap menguntungkan untuk melanjutkan atau membentuk interaksi (the comparison level). Jadi bila interaksi individu dengan kelompoknya di bawah comparison level, maka akan terjadi kemungkinan untuk mencari interaksi lain dengan kelompok lain yang lebih menguntungkan.

7. Tidak ada korelasi yang signifikan antara harga diri dengan kemampuan untuk berperan pada sistem politik yang ada $\left(r_{3.7}=0.0366 ; p=0.337\right)$.

Ada beberapa alasan dengan tidak terbuktinya hipotesis, yakni individu yang mempunyai harga diri tinggi (ditunjukkan pada kelompok pengunjuk rasa) dianggap lebih menghargai dan menghormati dirinya, berpandangan sejajar dengan orang lain (Frey \& Carlock, 1987), dan ini dianggap sebagai suatu dasar bahwa individu mampu berperan terhadap kondisi politik yang ada. 
Topik: Faktor-Faktor Penyebab Gerakan Sosial ..., Andik Matulessy dan Djamaludin Ancok

Padahal pada kenyataannya individu yang melakukan kegiatan unjuk rasa atau masuk dalam kelompok gerakan sosial, cenderung menampakkan perasaan tidak mampu berperan terhadap sistem politik yang ada. Oleh karena adanya perasaan tidak mampu itulah yang mempengaruhi mereka berpartisipasi untuk melakukan unjuk rasa. Jadi dapat dikatakan bahwa individu yang mempunyai harga diri yang tinggi belum tentu mempunyai kemampuan yang tinggi pula untuk berperan pada sistem politik yang ada.

Hasil lain dari analisis parsial ini adalah sebagai berikut:

1. Ada korelasi antara jadwal studi yang tidak terstruktur dengan ketidakpuasan subjektif individu $\left(r_{45}=-0.2392 ; p=\right.$ 0.005).

2. Tidak ada korelasi antara jadwal studi yang tidak terstruktur dengan identifikasi terhadap kelompok pengunjuk rasa $\left(r_{46}=0.0098 ; p=0.911\right)$.

3. Tidak ada korelasi antara jadwal studi yang tidak terstruktur dengan harga diri $\left(r_{47}=0.0843 ; p=0.333\right)$.

4. Ada korelasi antara ketidakpuasan subjektif dengan identifikasi terhadap kelompok pengunjuk rasa $\left(r_{56}=0.2214\right.$; $p=0.010$ ).

5. Ada korelasi antara ketidakpuasan subjektif dengan harga diri $\left(r_{57}=\right.$ $0.3362 ; p=0.000$ )

6. Tidak ada korelasi antara identifikasi individu terhadap kelompok pengunjuk rasa dengan harga diri $\left(r_{67}=-0,0299\right.$; $p=0.793$ ).

\section{Hasil Tambahan dan Diskusi}

- Pada metode analisis data penelitian terbaru, untuk menguji suatu model, maka digunakan suatu cara analisis data tertentu, dengan menggunakan program LISRELL atau EQS. Oleh karena penelitian ini bermaksud untuk menguji suatu model yang dikemukakan sebelumnya oleh Orum, maka cara analisis yang digunakan adalah model persamaan struktural (structural equation model). Namun demikian sebelumnya dilakukan penentuan goodness of fit dari model. berdasarkan hasil analisis didapatkan berbagai hasil sebagai berikut:

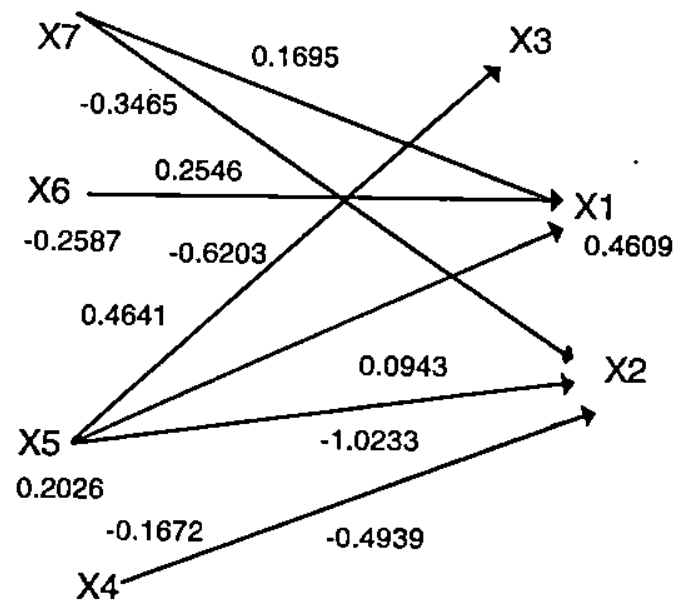

Partisipasi Mahasiswa dalam Gerakan Sosial (Prosposed Model III)

\section{Keterangan:}

$\mathrm{X}_{1}=$ Participation

$\mathrm{X}_{2}=$ Political Trust

$\mathrm{X3}=$ Political Efficacy

$X 4=$ Unstructured Studi Routine

$\mathrm{X} 5=$ Subjective Dissatisfaction

$\mathrm{X6}=$ Subgroup Identification

$X 7=$ Self Esteem

Berdasarkan gambar model di atas didapatkan hasil sebagai berikut:

1. Hasil-hasil yang sesuai dengan teori Orum (Allen et.al, 1980), yakni:

a. Identifikasi pada kelompok unjuk rasa berpengaruh positif terhadap partisipasi 
Topik: Faktor-Faktor Penyebab Gerakan Sosial ..., Andik Matulessy dan Djamaludin Ancok

dalam unjuk rasa.

b. Ketidakpuasan subjektif individu berpengaruh negatif terhadap kepercayaan pada sistem politik yang ada.

c. Ada hubungan yang negatif antara rutinitas studi yang tidak terstruktur dengan ketidakpuasan individu.

d. Ada hubungan antara rutinitas studi yang tidak terstruktur dengan harga diri.

e. Ada hubungan antara ketidak-puasan individu dengan identifikasi pada kelompok yang melakukan gerakan sosial.

f. Ada hubungan yang negatif antara ketidakpuasan individu dengan harga diri.

2. Hasil analisis yang tidak sesuai dengan model Orum adalah sebagai berikut:

a. Ketidakpuasan individu berpengaruh positif terhadap partisipasi dalam gerakan sosial.

Hal tersebut berarti mendukung teori Allen et. al. (1980) yang menyatakan bahwa deprivasi kumulatif, terutama yang berkaitan dengan perasaan tidak aman dari segi ekonomi individu yang semakin meningkat, akan mengarahkan keikutsertaannya dalam gerakan sosial.

Begitu pula pendapat Feuer (1969) dan Lofland \& Stark (1965) yang menemukan hubungan erat antara tipe kebutuhan atau permasalahan individu dengan tipe gerakan, semakin perasaan kekurangan meningkat, maka mereka cenderung semakin ingin mengikuti gerakan yang menyalahkan sistem yang ada.

Sarlito (dalam Himmah, 1995) mendukung pula dengan penemuannya bahwa aksi protes yang dilakukan mahasiswa karena adanya rasa frustasi akan posisinya sebagai intelektual muda, yang seharusnya mampu mengatasi ketimpangan-ketimpangan yang ada dalam suatu sistem, namun dia tidak mampu mengatasinya. Akhirnya karena dorongan frustasi yang didasari oleh perasaan tidak puas itulah yang mengarahkan mereka melakukan kegiatan unjuk rasa.

Hal ini didukung oleh penelitian Ladd (1966) dan Pettigrew (1964), yang menemukan bahwa gerakan kebebasan kulit hitam (The Black Liberation Movement) timbul, karena adanya ketidakpuasan mereka terhadap perbedaan periakuan yang dilakukan oleh pemerintah.

Memang tidak dapat disangsikan lagi bahwa ketegangan-ketegangan sosial yang terjadi di Indonesia maupun negara-negara lain seperti Korea Selatan, Filipina, RRC, berawal dari ketidakpuasan individu akan berbagai hal yang menyangkut kehidupan sosialnya. Sebagai contoh penanganan Kasus Udin, wartawan Bernas yang dianggap berlarut-larut, penanganan Marsinah atau pemberlakuan Undang-undang Perburuhan yang diberlakukan di Korsel, semua dianggap tidak memenuhi harapan masyarakat yang mendambakan sekali kebutuhan mendasar untuk diperlakukan secara adil.

Di sisi lain, bila dilihat dari data yang didapatkan dari perbandingan mean empiris ketidakpuasan subjektif dari subjek yang ikut serta dalam unjuk rasa ( $\mathrm{Xe1}=82.08$ ) dan subjek yang tidak ikut serta dalam unjuk rasa ( $\mathrm{Xe} 2$ $=71.70$ ) dengan rerata hipotetik ( $\mathrm{Xh}=$ 49.5), menunjukkan tingginya ketidakpuasan kedua kelompok tersebut terhadap berbagai hal dan kondisi yang ada. Hal tersebut mengindikasikan pula bahwa secara umum terjadi ketidakpuasan pada responden secara keseluruhan, baik yang berstatus sebagai aktivis maupun non-aktivis unjuk rasa. Hal ini bila dibiarkan akan bisa menjadi 
pemicu terjadinya berbagai macam gerakan sosial yang konstruktif, maupun yang sifatnya destruktif atau radikal.

Namun demikian bila kepuasan pada individu atau masyarakat sudah tercapai (misalnya penyelesaian tidak diberlakukannya lagi SDSB atau penggantian ganti rugi yang sesuai), maka akan mengarahkan berhentinya demo terhadap topik masalah tersebut.

Ironisnya kondisi sistem politik yang stabil tidak dapat berlangsung lama, sebab pasti ada hal-hal yang menimbulkan ketidakpuasan anggota masyarakat pada kondisi yang ada, sehingga gerakan sosialpun tidak pernah berhenti begitu begitu saja. Namun berbagai bentuk gerakan sosial ataun unjuk rasa dari tahun ke tahun tidak pernah selesai, misalnya setelah tahun 1960-an, muncul gerakan pengkoreksian terhadap langkah-langkah Orde Baru dari awal 70-an sampai sekarang.

b. Harga diri individu mempengaruhi partisipasi dalam gerakan sosial.

Menurut Frey\& Carlock (1987), individu yang mempunyai harga diri yang tinggi cenderung lebih menghargai dan menghormati dirinya, serta berpandangan sejajar dengan orang lain. Jadi adanya karakteristik tersebut membuat individu merasa yakin akan kemampuan dirinya, dan memandang dirinya kompeten dengan dunia yang dipersepsikannya (Cohen et.al. dalam Mischel \& Mischel, 1973). Oleh karena adanya karakteristik seperti itu, individu akan lebih mampu untuk mengikuti segala kegiatan di lingkungan sosialnya, antara ikut dalam organisasi gerakan sosial. Jadi dengan bekal harga diri yang tinggi, maka mereka akan lebih mempunyai keinginan untuk berpartisipasi dalam kegiatan gerakan sosial/unjuk rasa.

Sebaliknya individu dengan harga diri yang rendah, ia merasa rendah diri, tidak berdaya, malu-malu, dan tidak mampu menghadapi lingkungan secara efektif (Daradjat, 1985; Fitch, 1972). Akhirnya mereka cenderung menolak kegiatan di lingkungan sosialnya. Dan itu yang menjadi dasar ketidakinginan mereka untuk berpartisipasi dalam kegiatan gerakan sosial/unjuk rasa.

Hal itu dapat dilihat juga dari data secara keseluruhan, bahwa perbandingan mean empiris harga diri subjek yang ikut serta dalam demo (Xe1 = 69.61) dan subjek yang tidak ikut demo (Xe2 $=67.69)$, nampak bahwa para pendemo memiliki rerata yang lebih tinggi (harga diri lebih tinggi). Namun demikian secara keseluruhan nilai kedua kelompok tersebut lebih tinggi dari rerata hipotetik penelitian, yakni sebesar 40. Artinya kedua kelompok (aktivis \& non-aktivis) cenderung mempunyai harga diri yang tinggi, dan dimungkinkan kedua kelompok mampu mengikuti berbagai macam kegiatan di dalam maupun di luar kampus, namun kelompok pendemo (harga diri tinggi) mempunyai karakteristik lebih mampu berpartisipasi dalam sistem politik (Bryder, 1993), karena adanya dorongan yang lebih tinggi untuk mengambil resiko dibandingkan pada kelompok non aktivis.

c. Ada hubungan antara kepercayaan terhadap sistem politik yang ada dengan kemampuan berperan pada sistem politik.

Secara teoritik memang tidak ada yang mendasari hubungan langsung maupun tak langsung dari kedua varia- 
Topik: Faktor-Faktor Penyebab Gerakan Sosial ..., Andik Matulessy dan Djamaludin Ancok

bel di atas. Namun demikian secara asumtif dapat dijelaskan bahwa adanya keyakinan terhadap suatu hal akan mengarahkan individu untuk melakukan aktivitas yang berhubungan hal tersebutt. Artinya rasa percaya individu terhadap suatu sistem akan membuat individu merasa aman dan sesuai dengan sistem tersebut. Hal tersebut nantinya akan mengarahkan pada langkah selanjutnya untuk berperan dalam suatu sistem tersebut. Sebagai contoh anggota masyarakat yang percaya bahwa sistem politik yang ada mampu menyantuni mereka untuk tetap survive, maka mereka cenderung untuk berperan dengan baik pada sistem.

Contoh lain adalah proses yang terjadi di dalam sebuah kelompok tertentu yang diterangkan dengan social reinforcement-exchange theory, bahwa individu bila memasuki suatu kelompok tertentu dan kelompok tersebut menimbulkan kepuasan (reward/memunculkan kepercayaan) pada kelompok yang ada, maka akan meningkatkan interaksi individu dalam kelompok (Walgito, 1985). Dalam interaksi tersebut ada harapan minimal yang dianggap menguntungkan untuk melanjutkan atau membentuk interaksi (the comparison level), yang diasumsikan sebagai kemampuan untuk berperan. Jadi bila dalam interaksi di bawah comparison level (rendahnya kepuasan/individu menjadi kurang percaya), maka akan terjadi kemungkinan untuk mencari interaksi lain yang lebih menguntungkan.

Jadi berdasarkan analogi tersebut di atas diharapkan bisa menjelaskan keterkaitan antara kepercayaan terhadap sistem politik dengan kemampuan untuk berperan pada sistem politik yang ada. d. Jadwal studi yang tidak tersiuktur berpengaruh secara negatif terhadap kepercayaan pada sistem politik.

Hal tersebut berarti akan semakin menambah wawasan individu akan kondisi sistem politik yang ada di lingkungannya. Wawasan yang luas tersebut akan semakin membuat individu melihat segala ketimpangan-ketimpangan yang terjadi di lingkungan sosial. Dan hal ini akan mengarahkan pada ketidakpercayaan pada sistem politik yang ada.

Sebaliknya jadwal yang padat (terstruktur) akan mengarahkan individu untuk menyibukkan diri dengan segala kegiatan yang menyangkut dengan dirinya, mereka lebih sibuk berpacu dengan prestasi akademiknya, mematuhi kurikulum (Sintesa, 1993). Hal ini tanpa disadari akan mengarahkan mahasiswa pada kemandekan untuk berfikir tentang sistem politik yang ada. Akhirnya mereka percaya begitu saja pada sistem politik yang ada, bahkan mungkin ada sikap acuh tak acuh terhadap sistem politik yang ada.

e. Harga diri mempengaruhi secara negatif kepercayaan individu terhadap sistem politik yang ada.

Menurut Coopersmith (1967) harga diri mengarah pada evaluasi diri yang dirancang dan dilakukan oleh individu yang sebagian besar interaksinya dengan lingkungan, penerimaan dan perlakuan terhadapnya. Individu dengan harga diri yang tinggi mampu melihat segala ketidakenakan sebagai sesuatu yang tidak menekan, dan lebih berani bertindak (Daradjat, 1985).

Oleh karena itu individu dengan harga diri yang tinggi mampu melihat segala hal yang terjadi pada lingkungan- 
Topik: Faktor-Faktor Penyebab Gerakan Sosial ..., Andik Matulessy dan Djamaludin Ancok

nya secara lebih objektif, sehingga akan lebih cepat muncul ketidakpercayaan pada sistem politik yang melingkupinya.

Berbeda dengan individu yang mempunyai harga diri yang rendah. Mereka cenderung tidak berani bertindak, lemah, tidak berdaya, patuh, sehingga tidak mampu melihat lingkungan sosialnya secara lebih objektif. Akhirnya mereka lebih memunculkan perasaan percaya terhadap sistem politik yang melingkupinya.

f. Ketidakpuasan individu bepengaruh secara negatif terhadap kemampuan individu untuk berperan pada sistem politik yang ada

Jadi dapat dikatakan bahwa ketidakpuasan segala permasalahan yang muncul dalam dirinya tidak mampu diatasi, akan mendorong individu merasa tidak mampu berperan pada sistem politik yang ada. Perasaan tidak mampu berperan pada sistem politik yang ada ini akan muncul, bila individu sudah berkali-kali melakukan berbagai aktivitas untuk mempengaruhi kehidupan politik dan kebijaksanaan pemerintahan, namun tidak tercapai (Mas'oed \& MacAndrews, 1986). Namun demikian bila individu merasa puas terhadap segala hal/kondisi yang ada; yakni merasa diperlakukan secara adil, perasaan tidak tersingkir dari kekuasaan, mempunyai keinginan dan terlaksana, tidak adanya perasaan minoritas, tidak adanya perlakuan yang negatif dari penguasa, bebas berpendapat, dan mendapat perlakuan yang tidak berbeda. Hal-hal tersebut di atas akan mengarahkan perasaan berperan secara memadai dalam sistem perpolitikan yang ada. g. Tidak ada hubungan antara kemampuan berperan pada sistem politik dengan partisipasi dalam gerakan sosial

Hal ini bertentangan dengan pendapat Orum (dalam Allen et.al., 1980) bahwa individu yang merasa lebih mampu berperan dalam sistem politik, lebih berpartisipasi dalam gerakan sosial.

$\mathrm{Hal}$ tersebut bisa diterangkan pendapat DiRenzo (1990) bahwa hampir sebagian besar individu yang ikut serta dalam suatu gerakan ternyata didasari oleh ketidakmampuan berperan dalam sistem sosial politik yang ada. Sebagai contoh adalah gerakan yang dilakukan oleh masyarakat kulit hitam, kelompok Gay, kelompok Feminis, suku Indian, dan suku Aborijin, yang muncul akibat perasaan tidak berperan individu.

Begitu pula munculnya gerakan sosial yang terjadi di Indonesia, lebih banyak didasarkan pada ketidakmampuan untuk berperan memberikan solusi permasalahan terhadap sistem politik yang ada. Seperti yang dikemukakan Mas'oed \& MacAndrews (1986) bahwa partisipasi politik berupa demonstrasi, protes, dan tindak kekerasan lainnya, biasanya digunakan individu untuk mempengaruhi kehidupan politik dan kebijaksanaan pemerintahan, bila bentuk aktivitas lain tidak bisa dilakukan atau tidak efektif.

Hal di atas menunjukkan bahwa karena adanya keterbatasan kemampuan untuk berperan dalam sistem politik yang ada, membuat individu melakukan kegiatan unjuk rasa.

Selain itu secara nyata didapatkan bahwa individu yang diasumsikan lebih mampu berperan dalam sistem perpolitikan, misalnya aparat birokrasi, pengusaha yang mempunyai aksebilitas 
Topik: Faktor-Faktor Penyebab Gerakan Sosial ..., Andik Matulessy dan Djamaludin Ancok

kepemerintahan, ternyata cenderung tidak ikut serta dalam kegiatan gerakan sosial. Hal ini bertolak belakang dengan individu atau kelompok yang tidak mempunyai peran yang memadai dalam sistem politik, ternyata lebih menunjukkan aktivitas berpartisipasi dalam kegiatan unjuk rasa.

Secara lebih rinci dapat diterangkan pula dari hasil perbandingan rerata empiris pada kedua kelompok (aktivis dan non-aktivis), ternyata kelompok aktivis mempunyai rerata empiris yang lebih rendah $(\mathrm{Xe} 1=73$ ) dibandingkan dengan rerata empiris kelompok nonaktivis ( $\mathrm{Xe} 2=76.04)$. Hal ini berarti kelompok non-aktivis lebih merasa berperan dalam sistem politik dibandingkan kelompok aktivis. Walaupun bila dibandingkan dengan rerata hipotetik (Xh5 = 66.5), kedua kelompok mempunyai kemampuan di atas rerata hipotetiknya.

h. Tidak ada hubungan antara kepercayaan terhadap sistem politik yang ada dengan partisipasi dalam gerakan sosial.

Hal ini bertentangan dengan pendapat Orum (dalam Allen et.al., 1980) bahwa individu yang merasa tidak percaya dengan sistem politik yang ada, lebih berpartisipasi dalam aktivitas gerakan sosial.

$\mathrm{Hal}$ ini secara teoritis memang tidak ada dasar teori yang mendukung pendapat ini, karena sebagian besar mendukung teori yang menyatakan bahwa semakin tidak percaya individu terhadap suatu sistem, baik itu pemerintahan, organisasi, atau kelompok, maka akan mengarahkan pada dorongan untuk berpartisipasi dalam gerakan sosial. Namun demikian bila didasarkan pengamatan, kadang-kadang in- dividu yang melakukan gerakan sosial, ternyata tidak didasari oleh percaya atau tidaknya individu terhadap sistem yang ada, karena mereka cenderung acuh tak acuh dengan sistem politik yang ada. Artinya menjadi tidak terdeteksi secara nyata rasa percaya atau tidak individu terhadap sistem politik yang ada, di satu sisi mereka percaya dengan beberapa komponen sistem politik, misalnya organisasi profesi, sistem peradilan Tata Usaha Negara, DPRD I. Sementara di sisi lain mereka tidak percaya dengan komponen sistem politik yang lain, yakni sistem pemerintahan, pemilu, DPR Pusat. Jadi belum dapat dikatakan $100 \%$ bahwa faktor ketidakpercayaanlah yang mendorong terjadi suatu gerakan. Apalagi bila dilihat dari perbandingan hasil rerata empiris kelompok aktivis (Xe1 $=65,86$ ) dan kelompok non-aktivis (Xe2 $=77.85)$, ternyata di atas rerata hipotesis (Xh $=63$ ), artinya kedua kelompok masih dalam taraf kepercayaan pada sistem politik yang tinggi dibanding rerata hipotetik.

Berdasarkan kajian model di atas ada beberapa hal yang menonjol, yakni ada keterkaitan maupun pengaruh antara variabel ketidakpuasan subjektif individu dengan 6 variabel yang lain. Hal tersebut menunjukkan bahwa ketidakpuasan (diistilahkan pula dengan deprivasi relatif \& deperivasi kumulatif) terhadap berbagai hal atau kondisi yang ada di lingkungan sosialnya, mempunyai pengaruh yang sangat penting dalam pembentukan gerakan sosial, baik yang sifatnya destruktif maupun yang konstruktif.

Apalagi ketidakpuasan juga berpengaruh terhadap kepercayaan terhadap sistem politik yang ada (semakin tidak puas, maka semakin tidak percaya de- 
ngan sistem politik); kemampuan untuk berperan pada sistem politik (semakin tidak puas, maka akan semakin tidak mampu berperan terhadap sistem politik); harga diri (ketidakpuasan berkaitan erat dengan tingginya harga diri individu); identifikasi terhadap kelompok pengunjuk rasa (semakin tidak puas, maka semakin mengidentifikasikan dirinya dengan kelompok yang mengikuti gerakan sosial), dan rutinitas kuliah yang tidak terstruktur (ketidakpuasan berkaitan erat dengan jadwal yang padat).

Hasil lain menunjukkan bahwa walaupun sebagian responden menyatakan tak pernah ikut serta dalam suatu gerakan sosial atau kegiatan demo (80 orang dari 139 responden penelitian), namun demikian banyak yang mengisi pertanyaan yang berkaitan dengan jenis demo yang paling berkesan. Hampir sebagian besar menuliskan demo tentang PDI dan SDSB sebagai jenis demo yang paling berkesan bagi sebagian besar responden.

Selain itu bila dilihat dari rerata empiris skala $X 6$ (identifikasi terhadap kelompok unjuk rasa), baik dari kelompok aktivis (Xe1 $=127.83$ ) maupun kelompok non aktivis $(\mathrm{Xe2}=$ 106.14), yang dibandingkan dengan rerata hipotetis $(X h=61.5)$. Nampak sekali dari perbandingan tersebut, bahwa kedua kelompok sebenarnya mempunyai identifikasi yang tinggi dengan kelompok pengunjuk rasa, dalam artian sebenarnya ada keinginan untuk meniru aktivitas kelompok demo, berpandangan positif terhadap mereka, dan menginginkan mendapat hasil positif dari kegiatan kelompok tersebut.

Jadi sebenarnya di kalangan mahasiswa sendiri, mulai muncul kesadaran akan pentingnya gerakan-gerakan sosial muncul di kampus mereka. Serta ada kemungkinan bagi mereka untuk ikut serta dalam kegiatan-kegiatan tersebut. Namun demikian individu seperti inilah yang nantinya lebih brutal dalam kegiatan demo (menurut para aktivis dikatakan sebagai massa cair), mereka mudah terpancing oleh situasi untuk bertindak kasar, karena tidak didasari oleh pengetahuan yang memadai tentang aktivitas suatu gerakan. Mereka hanya ada keinginan untuk menjadi penonton semata, hanya ingin memunculkan rasa ingin tahu, tanpa pemikiran yang rasional. Merekalah yang kadang-kadang-kadang cepat terpancing, seperti melempar aparat kepolisian (terjadi pada wakru demo di UGM), mudah emosi, dan kurang kontrol dalam mengucapkan kata-kata. Berbeda dengan massa solid (aktivis), yang amat sangat tahu skenario suatu gerakan.

Sedang temuan lain adalah pada skala kepercayaan terhadap sistem politik, nampak sekali bahwa sebagian responden mempunyai kepercayaan yang tinggi pada Peradilan Tata Usaha Negara. Hal ini cukup menarik, karena badan Peradilan ini dapat dikatakan belum lama ada, namun mempunyai pamor yang baik.

Hal tersebut kemungkinan disebabkan oleh adanya berbagai kasus yang diselesaikan dengan baik (dianggap adil), seperti kasus pembredelan majalah Tempo, yang dimenangkan oleh PTUN, namun digagalkan oleh Mahkamah Agung. Namun hal ini juga harus diwaspadi, karena PTUN bukanlah badan peradilan tertinggi, yang dianggap sebagai alternatif terakhir permohonan suatu keadilan, tapi MA yang seharusnya dianggap sebagai cermin pemberi keadilan bagi masyarakat. Hal 
tersebut disebabkan oleh turunnya pamor wibawa MA dengan adanya kasus kolusi di lingkungan MA, serta munculnya vonis kontroversial, seperti kasus Pakpahan (mantan ketua SBSI), Kedung Ombo, dan perselisihan tanah antara ketua adat dan Gubernur Irian Jaya.

Selain itu bila dilihat data karakteristik responden pendemo, ternyata ditemukan mereka termasuk golongan menengah ke atas, bila dilihat penghasilan orang tua, serta tingkat pendidikan kedua orang tua. Hal tersebut tidaklah mendukung pendapat selama ini, bahwa terjadinya berbagai macam gerakan atau demo, lebih banyak disebabkan oleh faktor materi. Para aktivis yang melakukan demo, ternyata lebih banyak mengeluarkan uang pribadi untuk membiayai kegiatan mereka. Hal ini selaras dengan hasil penelitian dari Carden (Cook et.al., 1995), bahwa insentif materi bukanlah suatu motivator bagi para aktivis untuk melakukan gerakan sosial. Selain adanya pendapat yang menyatakan bahwa kegiatan demo selalu dibiayai oleh badan tertentu, ternyata sepengetahuan penulis tidaklah ditemukan. Kalaupun ada peran LSM, namun hanyalah peran sebagai pribadi anggota LSM. Biaya kegiatan sebagian besar didapatkan dari uang mereka sendiri ditambah dengan para pendukung informal, seperti dosen, pengurus LBH, anggota LSM, dan mahasiswa lain.

\section{Kesimpulan}

Berdasarkan hasil studi dapat disimpulkan bahwa gerakan sosial yang banyak terjadi belakangan ini, pada dasarnya merupakan aktivitas yang cenderung positif, karena merupakan bentuk respon individu terhadap terjadinya kesenjangan sosial yang terjadi pada suatu negara.

Gerakan sosial yang lebih dikenal dengan demonstrasi atau unjuk rasa ini lebih terorganisir, mempunyai struktur yang jelas, mampu bertahan lama, berusaha menyingkap persoalan politik, serta cenderung menghindari provokasi negatif (kekerasan). Selain itu, individu melakukan gerakan sosial sebagai bentuk dari keinginan mewujudkan aktualisasi dirinya sebagai aktor ilmiah yang dianggap bertanggung jawab terhadap segala ketidakseimbangan dalam segenap bidang kehidupan sosial.

Gerakan sosial ini bisa digunakan kontrol bagi sistem politik yang ada. Ini terlihat bahwa suatu kegiatan demo akan muncul bila sudah mulai ada permasalahan yang urgent, dan menyangkut kepentingan rakyat. Kegiatan demo akan berakhir bila permasalahan tersebut sudah.

Berdasarkan analisis jalur didapatkan hasil perhitungan model Orum, yakni partisipasi mahasiswa Indonesia dalam gerakan sosial adalah sebagai berikut:

1. Ada korelasi positif yang singnifikasi antara rutinitas kuliah yang tidak terstruktur dengan partisipasi dalam gerakan sosial.

2. Tidak ada korelasi yang singnifikan antara kepercayaan terhadap sistem politik yang ada dengan partisipasi dalam gerakan.

3. Ada korelasi yang sangat singnifikan antara identifikasi terhadap kelompok yang melakukan gerakan sosial dengan partisipasi dalam gerakan.

4. Tidak ada korelasi antara kemampuan berperan terhadap sistem politik dengan partisipasi dalam gerakan sosial.

5. Ada korelasi negatif yang sangat signifikan antara ketidakpuasan subjektif dengan kepercayaan terhadap sistem politik. 
6. Tidak ada korelasi yang signifikan antara identifikasi dengan kelompok yang melakukan gerakan sosial dengan kepercayaan terhadap sistem politik yang ada.

7. Tidak ada korelasi yang signifikan antara diri dengan kemampuan untuk pada sistem politik yang ada.

Selain analisis yang menggunakan analisis jalur, maka dilakukan analisis model persamaan struktur (structural equation model) dengan program EQS. Hasil analisis tambahan mendapatkan model baru dengan hasil sebagai berikut:

1. Ketidakpuasan subjektif berpengaruh positif pada partisipasi mahasiswa dalam gerakan sosial.

2. Harga ini terpengaruh positif pada partisipasi mahasiswa dalam gerakan sosial.

3. Kepercayaan pada sistem politik berkaitan dengan kemampuan beperan pada sistem politik.

4. Jadwal studi yang tidak terstruktur berpengaruh negatif terhadap kepercayaan pada sistem politik.

5. Harga diri berpengaruh negatif terhadap kepercayaan pada sistem politik.

6. Ketidakpuasan subjektif berpengaruh negatif pada kemampuan berperan dalam politik.

Berdasarkan kajian dua model di atas ada hal-hal yang menonjol, yakni ada keterkaitan maupun pengaruh antara variabel ketidakpuasan subjektif individu dengan enam variabel yang lain. Hal tersebut menunjukkan bahwa ketidakpuasan (diistilahkan pula dengan deprivasi relatif \& deperivasi) terhadap berbagai hal atau kondisi yang ada di lingkungan sosiainya, mempunyai pengaruh yang sangat penting dalam pembentukan gerakan sosial yang sufatnya destruktif maupun yang konstruktif.
Apalagi ketidakpuasan juga berpengaruh terhadap kepercayaan sistem politik yang ada (semakin tidak puas, maka semakin tidak percaya dengan sistem politik); kemampuan untuk berperan pada sistem politik (semakin tidak puas, maka akan semakin tidak mampu berperan terhadap sistem politik); harga diri (ketidakpuasan berkaitan erat dengan tingginya harga diri individu); identifikasi terhadap kelompok pengunjuk rasa (semakin tidak puas, maka semakin mengidentifikasikan dirinya dengan kelompok yang mengikuti gerakan sosial), dan rutinitas. kuliah yang tidak terstruktur (ketidakpuasan berkaitan erat dengan jadwal yang padat).

Jadi semakin banyak kondisi ketidakadilan, kesewenang-wenangan, kesenjangan, serta kondisi yang negatif lain, maka kegiatan demopun akan semakin marak. Padahal adanya demo atau tidak berkatan erat sekali dengan kestabilan di suatu negara. Jadi sebenarnya faktor subjective dissatisfaction, yang bisa menjadi tolok ukur situasi dan kondisi suatu negara.

\section{Saran-Saran}

Dari berbagai kesimpulan yang didapatkan dari hasil studi ini dapat diberikan berbagai saran penting yakni:

\section{Pada Pemerintah}

Urgensi dari ketidakpuasan subjektif individu yang perlu diwujudkan dengan cara mengurangi terjadinya kesenjangan sosial, menyelesaikan segala permasalahan secara lebih adil dan terbuka, dan meningkatkan perhatian terhadap permasalahan yang terjadi di masyarakat, walau sekecil apapun.

Sebaliknya memberikan kesempatan yang lebih banyak bagi mahasiswa untuk menyampaikan aspirasinya, karena bagai- 
Topik: Faktor-Faktor Penyebab Gerakan Sosial ..., Andik Matulessy dan Djamaludin Ancok

manapun juga segala protes yang dilakukan cenderung bermaksud positif, karena topik-topik yang dimunculkan berkatan erat dengan isu sosial yang dipandang penting untuk diselesaikan. Selain itu pemberian kesempatan bagi mahasiswa untuk melakukan demio (terutama demo yang terorganisasi) lebih baik dilakukan, daripada melarangnya, karena pelarangan akan semakin meningkatkan frustasi bagi mereka, sehingga carà yang dilakukan akan semakin brutal. Yang periu diperhatikan adalah para pendemo, yang melakukan kegiatan tanpa tahu sebenarnya kegiatan demo.

Di sisi lain perlu dimunculkan pandangan bahwa kegiatan demo adalah kegiatan yang positif, karena bisa dijadikan sebagai kontrol yang baik secara khusus terhadap prilaku atau aparat yang kurang bertanggung jawab, dan secara umum bisa menjadi penetralisir kondisi politik yang penuh dengan ketidakmampuan (korupsi, kolusi, dsb.).

\section{Bagi Mahasiswa}

Perlu dimunculkan sikap kritis bagi mahasiswa, berupa kemampuan untuk tang: gap dan sensitif terhadap segala hal yang menyangkut kesenjangan sosial yang terjadi di segenap bidang kehidupan. Jadi mahasiswa jangan hanya disibukkan oleh segala hal yang menyangkut perkuliahan saja, namun perlu diasah dengan segala kegiatan yang menyangkut kepedulian terhadap sistem politik yang berlaku saat ini. Jadi mahasiswa tidak hanya pasif terhadap segala sesuatu yang terjadi di negara ini. Penting sekali untuk mengisi waktu dengan kegiatan-kegiatan yang positif, tidak bersikap acuh tak acuh terhadap segala sosial yang negatif. Secara lebih luas lagi perlu dimunculkan kepedulian terhadap segala peran dalam mengisi kehidupan politik dalam bentuk modul-modul perkuliahan.

\section{Bagi Peneliti selanjutnya}

Bagi peneliti lain yang ingin mengulas kegiatan gerakan sosial lebih lanjut, perlu memperhatikan beberapa hal, yakni:

a. Peningkatan jumlah subjek penelitian dan lokasi penelitian dan lokasi penelitian, terutama daerah-daerah yang dianggap marak dalam demo seperti Salatiga dan Bandung, sehingga lebih bisa menggambarkan situasi dan kondisi gerakan sosial mahasiswa di Indonesia secara lebih lengkap dan akurat.

b. Perlu menggunakan alternatif cara penelitian yang lebih efektif, misalnya dengan cara menggunakan metode kualitatif, sehingga bisa lebih mengungkapan hal-hal yang tidak dapat diungkap dengan cara kuantitatif. Penggabungan kedua metode ini akan lebih bisa memberi hasil yang optimal.

c. Perlu merevisi lebih lanjut skala penelitian, terutama skala yang mengukur tentang partisipasi mahasiswa dalam gerakan sosial, untuk lebih mendapat hasil yang lebih baik.

\section{Daftar Pustaka}

Ahmadi, A. 1991. Psikologi Sosial. Rineka Cipta. Jakarta.

Allen, D.E., Guy, RF., Edgley, CK. 1980. Social Psychology as Social Process. Wadworth Inc. California.

Altbach, Philip, G. 1988. Politik \& Mahasiswa: Perspektif \& Kecenderungan Masa Kini. Gramedia, Jakarta.

Cook, K.S., Fine, G.A., House, J.S. 1995. Sociological Perspectives on Social Psychology. Allyn \& Bacon. Massachussets.

DiRenzo, G. 1990. Human Social Behavior. Concepts \& Principles of Soci- 
Topik: Faktor-Faktor Penyebab Gerakan Sosial ..., Andik Matulessy dan Djamaludin Ancok

ology. Holt, Rinehart \& Winston. New York.

Feuer, Lewis S. 1969. The Conflict of Generation. Basic Book Inc. New York.

Frey, Diane, Carlock, C.J. 1987. Enhacing Self Esteem. Ancelerated Development Inc. Muncie. New York.

Gerungan, W.A. 1996. Psikologi Sosial. PT Eresco. Bandung.

Geschwender, JA. 1967. Continuities in the Theories of Status Consistency and Cognitive Dissonance.Social Forces. 46, 160-171.

Hagopian, Mark N. 1978. Regimen, Movements \& Ideologies: A Comparative Introduction to Political Scieence. Longman. New York.

Haryanto. 1987. The Phases of the Indonesian Students Movements 19661978: Descriptive Study. A Thesis Presented to The Faculty of The Graduate School Ateneo de Manila University. Tesis. Tidak diterbitkan.

Lipset, Seymor M. 1968. Students \& Politics in Comparative Perspective. Deadalus. Vol: 97, No. 1,2-3.

Lindzey, G \& Aronson, E. 1975. The Handbook of Social Psychology, AddisonWesley Publishing Co, Inc. New York.

Lofland, John, Stark, Rodney. 1965. Becoming A World Saver: A Theory of Religious Conversion. American Sociological Review, 30, 862-874.
Mas'oed, M. Mac Andrews, C. 1986. Perbandingan Sistem Politik. Gadjah Mada University Press. Yogyakarta. Nasri, Imron. 1993. Mahasiswa dan Masa Depan Politik Indonesia. Bentang Offset. Yogyakarta.

Orum, AM. 1974. On Participation in Political Protest Movements. Journal of Applied Behavior Science. 10, 181-207.

Parwoto. 1995. Mereka Gelisah Mereka Melawan. Himmah. No. 01/Th XXVIII/1995. 52-56.

Stallings, RA. 1973. Patterns of Belief in Social Movements: Clarifications from and Analysis of Environmental Groups. Sociological Quarterly. 14, 465-480.

Walgito, Bimo, 1995. Psikologi Kelompok. Hand-out Kuliah. Tidak Diterbitkan. Yogyakarta.

Wiggins, J.A., Wiggins, B.B., Zanden, J.V. 1994. Social Psychology. McGrawHill, Inc. New York.

Yumpi, F.R. 1996. Perilaku Demonstran: Studi tentang Kelompok Gerakan Sosial Mahasiswa Forum Mahasiswa Jombang. Laporan Penelitian. Tidak diterbitkan. Fakultas Psikologi UGM. Yogyakarta.

_., (1996). Perjuangan Mewujudkan Demokrasi dari Demonstrasi. Pijar. No: 6/th. VIII/1996. 16-19. 